\title{
Efektifitas Metode Mean Arterial Pressor (MAP) terhadap Deteksi Dini Preeklamsi Pada Ibu Hamil
}

\author{
Sumarni \\ Prodi Kebidanan, Fakultas Keperawatan dan Kebidanan, Universitas Megarezky ${ }^{1}$ \\ e-mail: ${ }^{1}$ sumarni.megarezky@gmail.com
}

\begin{abstract}
Approximately 2-7\% of pregnant women experience complications of preeclampsia, many of the risk factors that can cause preeclampsia, which ultimately lead to a high rate of maternal mortality and morbidity. Small changes in blood pressure are a marker of the risk of developing preeclampsia. The study found out the effectiveness of the Mean Arterial Pressor (MAP) method for early detection of preeclampsia in pregnant women. The research design used was Observational with a Cohort Study (Prospective) approach. This research was conducted at Puskesmas Pasttimgalloang in 2019. The sample in this study were pregnant women who met the inclusion criteria, as many as 30 respondents. The results of statistical tests using the Chi Square test obtained the value of $p=0.000$, because the value of $p=0.000<\alpha(0.05)$, the measurement of the MAP value is effective for early detection of preeclampsia.
\end{abstract}

Keywords: MAP, preeklampsia, blood pressure

\begin{abstract}
ABSTRAK
Sekitar 2-7 \% wanita hamil mengalami komplikasi preeklamsia, banyaknya factor resiko yang dapat menyebabkan preeklamsia, yang akhirnya menyebabkan tingginya angka mortality dan morbidity pada ibu. Perubahan kecil dalam tekanan darah adalah penanda resiko berkembangnya preeklamsia. Penelitian mengetahui efektifitas Metode Mean Arterial Pressor (MAP) terhadap deteksi dini preeklamsi pada ibu hamil. desain penelitian yang digunakan adalah Observasional dengan pendekatan Studi Kohor (Prospektif). penelitian ini dilaksanakan di Puskesmas Pasttimgalloang pada tahun 2019. Sampel dalam penelitian ini adalah ibu hamil yang memenuhi kriteria inklusi yaitu sebanyak 30 responden. Hasil uji statistik dengan menggunakan uji Chi Square di peroleh nilai $\mathrm{p}=0,000$, karena nilai $\mathrm{p}=0,000<\alpha(0,05)$ maka pengukuran nilai MAP efektif untuk mendeteksi secara dini Preeklamsia.
\end{abstract}

Kata kunci: MAP, preeklampsia, tekanan darah

\section{PENDAHULUAN}

Preeklamsia masih menjadi ancaman serius di dunia kesehatan oleh karena berkontribusi terhadap morbiditas dan mortalitas maternal dan perinatal. Angka kejadian preeklamsia diseluruh dunia berkisar antara 5-10\%. Di Indonesia, lebih dari lebih $30 \%$ kematian ibu hamil pada tahun 2010 di sebabkan oleh preeklamsia. Hal ini dikarenakan ketidaktahuan dan keterlambatan mencari pertolongan setelah adanya gejala klinis (UNICEF, 2017).

Diperlukan kemampuan diagnosis hipertensi dalam kehamilan dan penyakit penyerta kehamilan dengan meningkatkan kualitas ANC salah satunya deteksi dini faktor-faktor resiko. Selama ini terdapat berbagai metode yang dapat digunakan untuk mendeteksi factor resiko preeklamsia yaitu factor maternal dan riwayat penyakit ibu seperti Uterine Arteriy Doppler (UAD), Volume Placenta dan 3D Power Doppler, dan Blood Pressor and Mean Artery Pressor (MAP).
Perubahan kecil dalam tekanan darah adalah penanda resiko berkembangnya preeklamsia. Perempuan yang mengalami preeklamsia memiliki tekanan darah sistolik lebih tinggi dan MAP sebelum timbulnya penyakit klinis. . MAP lebih prediktif pada wanita preeklamsia trimester pertama dan atau kedua dari bacaan sistolik ataupun diastolic. MAP yang diukur antara usia kehamilan 11-19 minggu memiliki tingkat positif palsu $10 \%$ dengan tingkat deteksi 74,3\%, 62,9\% dan 49,3\% pada awal PE, PE premature, dan jumlah PE. Pada usia kehamilan 20-24 mimggu, tingkat positif palsu tetap $10 \%$ dengan tingkat deteksi $84,3 \%, 65,7 \%$, dan $52,5 \%$ pada awal PE, PE premature, dan jumlah PE. MAP memilikiSensitifitas $93 \%$ dan spesifitas $62 \%$ (Rano K. Sinuraya dkk 2017).

Akoleker (2012) dalam penelitiannya mendapatkan hasil bahwa terdapat korelasi linier antara Mean Arteri Pressor dengan Preeklamsia. Taslim et all (2016) juga mendapatkan hasil yang sama dimana MAP secara signifikan berhubungan dengan preeklamsia dan MAP 
yang tidak normal beresiko 11,69 kali untuk terjadi preeklamsia.

Dari data Dinas Kesehatan Sulawesi Selatan tahun 2015149 jumlah kasus kematian ibu,kondisi tersebut menandakan belum tecapainya angka yang ditargetkan.Jumlah tersebut mengalami peningkatan dari tahun sebelumnya sebesar 138 kasus.Hipertensi dalam kehamilan menyumbang 32 kasus $(21,48 \%)$ dari total angka kasus kematian ibu di Sulawesi Selatan dengan salah satu penyebabnya adalah keterlambatan deteksi dini faktor resiko dan rendahnya kualitas Antenatal Care(SULSEL PROV,2015).

\section{Hipotesis}

Adapun hipotesis dalam penelitian ini adalah sebagai berikut:

1. Hipotesis Alternatif (Ha)

Metode MAP efektif terhadap deteksi dini preeklamsia di wilayah Puskesmas Pattingalloang.

2. Hipotesis $\mathrm{Nol}(\mathrm{HO})$

Metode MAP tidak efektif terhadap deteksi dini preeklamsia di wilayah Puskesmas Pattingalloang.

\section{METODE}

Desain penelitian yang digunakan adalah Observasionaldengan pendekatan Studi Kohor (Prospektif), study kohor dimulai dengan mengidentifikasi faktor resiko timbulnya efek, yang sering disebut kausa. Tempat penelitian ini dilaksanakan di Puskesmas Pasttimgalloang. Waktu penelitian pada bulan Februari - November 2019.

Populasi dalam penelitian ini adalah semua ibu hamil yang datang berkunjung di Puskesmas Pattingalloag mulai bulan Februari - Juni 2019 sebanyak $217 \mathrm{ibu}$ hamil. Sampel penelitian adalah sebagian ibu hamil yang diambil dengan menggunakan tekhnik purposive sampling yaitu sebanyak $30 \mathrm{ibu}$ hamil dengan kriteria :

a. Inklusi

1) Semua ibu hamil yang berkunjung dengan umur kehamilan $\leq 20 \mathrm{mg}$.

2) Bersedia diikutsertakan dalam penelitian

3) Berdomisili diwilayah PKM Pattingalloang .

b. Eksklusi

1) Pasien dengan kehamilan molahidatidosa.

2) Ibu hamil yang berdomisili di luar wilayah PKM Pattingalloang.

3) Ibu hamil yang berkunjung $>20 \mathrm{mg}$.

Instrumen yang digunakan adalah alat pengukur tensi spignomanometer dan lembar observasi. Analisis yang dilakukan terhadap setiap variable dependen dan independen dengan menggunakan uji statistik chisquare.

\section{HASIL}

Analisis bivariat dilakukan untuk mengetahui hubungan variabel independen dengan variabel dependen. Uji statistik yang digunakan adalah uji Chi Square dengan tingkat kemaknaan $\alpha=0,005$.

Hubungan variabel independen terhadap variabel dependen di jabarkan sebagai berikut :

Tabel 1. Efektifitas Mean Arterial Pressure Terhadap Deteksi Dini Preeklamsia Puskesmas Pattingalloang Makassar Tahun 2019

\begin{tabular}{|c|c|c|c|c|c|c|c|c|}
\hline \multirow{3}{*}{$\begin{array}{l}\text { Nilai } \\
\text { MAP }\end{array}$} & \multicolumn{4}{|c|}{ Terjadi Preeklamsia } & \multicolumn{2}{|c|}{ Total } & \multirow{3}{*}{$\mathbf{P}$} & \multirow{3}{*}{$\alpha$} \\
\hline & \multicolumn{2}{|l|}{ Ya } & \multicolumn{2}{|c|}{ Tidak } & \multirow{2}{*}{$\mathbf{N}$} & \multirow{2}{*}{$\%$} & & \\
\hline & $\mathbf{N}$ & $\%$ & $\mathbf{N}$ & $\%$ & & & & \\
\hline Positif & 9 & 90 & 1 & 10 & 10 & 100 & \multirow{3}{*}{0.000} & \multirow{3}{*}{0,05} \\
\hline Negatif & 1 & 5,0 & 19 & 95,0 & 20 & 100 & & \\
\hline Total & 10 & 33,3 & 20 & 66,7 & 30 & 100 & & \\
\hline
\end{tabular}

Tabel 1 menunjukkan bahwa dari $10 \mathrm{ibu}$ hamil MAP positif terdapat 9 orang (90\%) mengalami preeklamsia, lorang (10\%) tidak mengalami preeklamsia. Sedangkan dari 20 ibu hamil MAP negatif terdapat 1 orang $(5,0 \%)$ mengalami preeklamsia , 19 orang $(95,0 \%)$ tidak terjadi preeklamsia.

Hasil uji statistik dengan menggunakan uji Chi Square dengan menggunakan tabel kontingensi 2 x 2 di peroleh nilai $\mathrm{p}=0,000$, karena nilai $\mathrm{p}=0,000<\alpha(0,05)$ maka Ha di tolak dan Ho diterima artinya pengukuran nilai MAP efektif untuk mendeteksi secara dini Preeklamsia.

\section{PEMBAHASAN}

Berdasarrkan hasil penelitian yang dilakukan diwilayah kerja Puskesmas Pattingalloang jumlah responden yang nilai MAP positif sebanyak 10 responden (30\%) dengan terjadi preeklamsia sebanyak 9 responden $(30 \%)$ dan tidak terjadi preeklamsia sebanyak 1 responden (3,33\%). Sedangkan responden yang nilai MAP negatif sebanyak 20 responden $(66,66 \%)$ terjadi preeklamsia sebanyak 1 responden $(3,33 \%)$ dan tidak terjadi preeklamsia sebanyak 19 responden $(63,33 \%)$.

Penelitian ini sejalan dengan penelitian Chan et al ( 2017 ) dalam penelitiannya yang melibatkan 12.915 wanita (326 hipertensi gestasional dan 82 preeklamsia) menemukan hasil bahwa MAP trimester 1 dan karakteristik ibu hamil mampu menjadi prediktor hipertensi gestasional dan preeklamsia dengan tingkat deteksi 76\%. Gasse et al (2017 ) dalam hasil penelitiannya juga mengatakan bahwa mengukur menggunakan perangkat otomatis pada usia 11-13 
minggu berguna untuk mengidentifikasi wanita beresiko tinggi preeklamsia. Kuc et al. (2013) dalam penelitiannya tentang model prediktor mengatakan model terbaik terdiri dari karakteristik ibu, MAP, protein plasma, TM 1, A Disintegrin dan Metalloproase12 dengan kemampuan interpretasi $72 \%$. Gallo et al.(2014) juga menemukan hasil bahwa MAP adalah metode skrining terbaik untuk preeklamsia jika diambil pada usia 11-13 mimggu dan 20-24 mimggu dengan kemampuan interpretasi $84,3 \%$ dan $52,5 \%$. . Sejalan dengan temuan Nokele et al (2014) bahwa nilai MAP lebih tinggi pada wanita preeklamsia dibandingkan dengan yang tidak preeklamsia.

Hal tersebut terjadi ketika ibu hamil tidak mampu beradaptasi terhadap perubahan sistem kardiovaskuler secara fisiologis akan menyebabkan ketidakseimbangan antara volume darah dan curah jantung terhadap vasodilatasi perifer yang terjadi, sehingga akan menyebabkan terganggunya gaya darah terhadap dinding pembuluh darah. Wanita yang mengalami preeklamsia akan mengalami densivitas terhadap angiotensin II karena adanysa perubahan konformasi reseptor angiotensin II tipe 1. Peningkatan kepekaan terhadap angiotensin II ini menyebabkan meningkatnya pelepasan aldosteron, menimgkatnya vasokontriksi otot polos, meningkatnya reabsorbsi $\mathrm{Na}$ dan retensi air sehingga tekanan darah akan meningkat termasuk tekanan sistole, diastole dan MAP ( Nokele et al, (2014).

Berdasarkan hasil penelitian, setelah dilakukan analisa data hasil menunjukkan responden nilai MAP positif yang terjadi preeklamsia sebanyak 9 responden dengan presentase $(90 \%)$, sedangkan tidak terjadi preeklamsia sebanyak 1 responden $(10 \%)$. Untuk nilai MAPnegative, $1(5,0 \%)$ responden yang terjadi preeklamsia dan sebanyak $19(95,0 \%)$ responden yang tidak terjadi preeklamsia.

Hasil penelitian ini juga menunjukkan adanya 1 responden $(10 \%)$ yang nilai MAP positif tapi tidak terjadi preeklamsia, pasien ini pada diagnosis akhir adalah Hipertensi Gestasional atau hipertensi sesaat. Hal ini menurut analisa peneliti walaupun metode Mean Arterial Pressure merupakan prediktor yang baik untuk mendeteksi preeklamsia tetapi diperlukan metode- metode lain seperti ROT (Roll Over Test), dan perhitungan nilai IMT (Indeks Massa Tubuh) serta anamnesis faktor resiko lain.

Sedangkan adanya responden yang nilai MAP < $90 \mathrm{mmHg}$ tapi terjadi Preeklamsia di usia kehamilan $32 \mathrm{mg}$ hal ini disebabkan karena banyaknya faktor resiko lain yang mungkin di miliki oleh pasien tapi tidak terskrining oleh peneliti misalnya riwayat DM yang jarang ibu ketahui dan menurut peneliti penelitian mengenai hubungan riwayat penyakit DM pada ibu dan kasus preeklamsia perlu dilakukan penelitian yang lebih mendalam karena merupakan kejadian preeklamsia yang sangat berbahaya.

.Hasil analisa data menggunakan uji Chi Square dengan nilai $\mathrm{p}$ sebesar $0,000(\mathrm{p}<0,05)$, menunjukkan bahwa metode Mean Arterial Pressure (MAP) efektif terhadap deteksi dini preeklamsia dapat diterima. Metode metode lain pun harus juga digunakan untuk lebih meningkatkan kualitas skrinimg. Sehingga factor- factor resiko preeklamsia baik melalui anamnesis maupun metode pengukuran dapat dilakukan secara bersama-sama

Peneliti berasumsi metode Mean arterial Pressor sangat efektif digunakan untuk mendeteksi dini kejadian preeklamsia. Adanya evaluasi skrining secara aktif terhadap resiko terjadinya preeklamsia sehingga upaya pencegahan preeklamsia bisa optimal yang pada akhirnya menurunkan morbiditas dan mortalitas yang diakibatkan oleh preeklamsia. Hal ini dapat menggambarkan bahwa pelayanan Antenatal care yang dilakukan berkualitas. Saat ini pencegahan preeklamsia lebih ditekankan dari pada penanganan karena jauh lebih baik sehingga pemberian Aspirin dosis rendah dan suplemen kalsium dapat di lakukan.

\section{KESIMPULAN}

Berdasarkan hasil penelitian Efektifitas Metode Mean Arterial Pressure terhadap Deteksi Dini Preeklamsia di Puskesmas Pattingalloang Makassar Tahun 2019 yaitu nilai $\mathrm{p}=0,000<\alpha 0,05$ dengan demikan H0 diterima dan Ha diterima.

Adapun yang menjadi saran penulis adalah Bagi Fasilitas pelayanan Kesehatan Ibu dan Anak diharapkan Deteksi dini preeklamsia dengan mengenali faktor-faktor resiko preeklamsia perlu ditingkatkan lebih intensif melalui peningkatan pengetahuan tenaga kesehatan khususnya bidan sebagai ujung tombak pelayanan kesehatan ibu dan anak karena masih banyaknya tenaga kesehatan yang belum terpapar mengenai preeklamsia up date. Bagi peneliti selanjutnya agara penelitian selanjutnya dapat dilakukan dengan melibatkan lebih banyak Metode seperti ROT (Roll Over Test) dan Perhitungan IMT (Indeks Massa Tubuh) dengan menggunakan sampel yang lebih besar.

\section{DAFTAR PUSTAKA}

1. Cunningham, F,G.2009.Hypertensive Disordets In Pregnancy, in William Obstetri, 22 .New York. Medical Publishing Division

2. Departemen Kesehatan Profil Kesehatan Sulawesi Selatan 2015

3. Departemen Kesehatan Profil Kesehatan Kota Makassar 2015

4. Ircham M, 2014. Metodologi Penelitian. Yogyakarta: Fitramaya

5. Kementrian Kesehatan RI 2016 Riskesdes 20016

6. Kementerian Kesehatan RI 2016. Siskernas 2016

7. Manuaba, IB,2010. Fisiologi Kehamilan, Jakarta : Penerbit Buku Kedokteran 
8. POGI. 2016. Diagnosis dan Tata Laksana Preeklamsia. Perkumpulan Obstetri dan Ginekologi Indonesia

9. Prawirohardjo, Sarwono. 2011. Ilmu Kebidanan. Jakarta : Yayasan Bina Pustaka

10. Roberts, J.M.et al.2012. ACOG Guidelines: Hipertension In Pregnancy. American College of Obstetricans and Gynecologist

11. Rano K, DKK 2017. Biomarker PIGF?sFltsebagai Pendeteksi Dini Preeklamsia

12. Saryono, 2011. Metodologi Penelitian Kesehatan. Jogjakarta: Mitra Cendikia Press

13. Suprihatin, E. And Norontoko, D A. 2015. Prediction of preeklamsia by a Combination of body Mass Indeks (BMI), Mean Arterial Pressor (MAP) and Roll Over Test (ROT)

14. Sherwoood, L. 2014. Fisiologi manusia dari sel ke sistem. Edisi 8. Jakarta:EGC

15. Unicef, 2017. The Situasion of Children and women in Indonesia. Diakses pada tanggal 2 Desember 2018

16. Wibowo, N. Et Al. (2016). Pedoman Nasional Pelayanan Kedokteran: Perkumpulan Obstetri dan Ginekologi Indonesia 